\title{
An Exploration of Mathematics Teachers' Reflection on Their Teaching Practices
}

\author{
Siti Mistima Binti Maat \\ Mathematics Unit, Technical Foundation Section \\ Universiti Kuala Lumpur Malaysia France Institute, Bangi, Selangor, Malaysia \\ E-mail: sitimistima@gmail.com \\ Effandi Zakaria (Corresponding author) \\ Department of Educational Methodology and Practice, Faculty of Education \\ Universiti Kebangsaan Malaysia, Bangi, Selangor, Malaysia \\ Tel: 60-3-8921-6279 E-mail: effandi@ukm.my
}

\begin{abstract}
This study focuses on understanding the reflection on teaching practices of two mathematics teachers teaching technical mathematics in a technical institute. For the purpose of this study, reflection is considered as the teachers' interpretation of their teaching practices. These teachers were interviewed to describe their teaching practices aspects including the teaching plan, teaching strategy, goal setting, their strength and weakness of being a teacher and handling students' problem in class. A class observation was done by the researcher to get more information related to their teaching in class. The finding shows that the teachers managed to reflect on what they have done in the class but they could not identify the right action to be taken.
\end{abstract}

Keywords: Teaching practices, Mathematics teachers, Technical institute, Reflection

\section{Introduction}

The interest in reflection was started by Dewey (1993) to increase the professional development of teachers. Some other studies on reflection have been carried out by Doyle (1990) and Nelson (1993). The purpose of teachers' reflection is to identify problems during teaching practices (Kwon \& Orrill, 2007) which are important for teachers to make sense of students' understanding and how teaching might relate to that understanding. When discussing teaching practices, the definition varies in many aspects. These practices include all activities carried out during teaching and learning process in classrooms. Some researchers consider teaching practices focusing on specific teaching method like inquiry based instruction.

Understanding teaching practices will enable these students to engage in their learning process which assist them to form their interest, creativity, application, discovering and gathering ideas in mathematics. Teachers are expected to teach students manage and facilitate their learning in the classroom. They are responsible in teaching and learning of Mathematics which require them to outline their teaching materials and plan daily lesson effectively (Noraini, 2006). Since students acquire most of their learning process in the classroom therefore it is anticipated that teaching should be a major factor influencing the students' achievement (Koon Shing Leung, 2005). The main factor influencing teaching practice is these teachers' beliefs. How these teachers envision and enact these roles within the classroom was controlled by their beliefs (Cross, 2009).

In order to promote good effective teaching practices, consideration must be given to teaching goals. As mentioned by NRC (2001), good teaching practices must consist of aspects such as conceptual understanding, procedural fluency, strategic competence, adaptive reasoning and productive disposition. There is a distinct difference in teaching practices particularly in the way the teacher asks some questions in the class (Cross, 2009).

\section{Conceptual Framework}

The importance of reflection is critical in order to relate between theory and practice. There are two types of reflection which include reflection in action and reflection on action (Schon, 1987). Escudero and Sanchez (2007) 
stated that there had been considerable interest in describing how an activity in a classroom was organized. Teachers' reflection on their teaching practices provides chances for them to view their students' learning and the teaching materials. A study on teachers' reflection was conducted by Kwon and Orill (2007) which focused on the teaching capacity within the teacher's communication in class. Reflection can be used as a tool to investigate teaching practices in order to achieve meaningful educational reform (Cohen \& Hill, 2000) and to help them in thinking about teachers' activity in the class (McNergney \& McNergney, 2004). It is also imperative to develop knowledge on how to teach effectively through analyzing the real situation in class (Smith, 2001). Based on reflection, changes in teaching practices can be implemented provided that the teachers have broad knowledge in mathematics, pedagogy and on their students (Smith, 2001).

\section{Research Objective}

The objective of this study is to investigate the mathematics teachers' teaching practices that are related to teaching preparation, goal setting, expectation from the class, teaching strategy, strength and weakness of being a Mathematics teacher and the problem faced as well as their reflection on what they have done in the class.

\section{Methodology}

The research design is an exploratory case study. The aim of this research was to understand how these teachers reflected on their teaching practices and their students' understanding. These ideas presented in this study are part of the extensive work exploring these teachers' practices in the classroom. Some problems that were faced by these teachers were also addressed. An interpretive case study was used to collect data from participant teachers through variety data sources including interview and class observation.

\subsection{Participants of the study}

They were two teachers who participated in this study. The first educator, Miss Eliz, is an experienced lecturer who has qualification at master level in Mathematics education. She has been teaching Mathematics for more than ten years to the diploma and degree students in a technical institute. The second educator, Miss Yaqeen only has three years experience in teaching mathematics at diploma level. She is a degree holder in Mathematics from a local university.

\subsection{Interviews}

The researcher has developed the interview questions which were adapted from Newton (2009). Although Newton has given the questions to the student's teachers but the scope of the questions were mostly related to the aspect of teaching practices in this study. The interview question focused on the number of years in the teaching experience, the teachers' preparation before their mathematics class begins, the teachers setting of goals in their teaching and their expectation from the class that they teach. The teachers were also asked about their teaching method; whether they do reflection after teaching; to identify their strength and weaknesses in teaching. The aspect of the problems that the teachers encounter in class was also raised in the interview question as well as the challenges that they face during teaching. The last part of the interview ended with describing good mathematics teachers and effective mathematics teaching.

The procedure of the interview was done through emailing the questions to the selected teachers. Since some of the given answers were not clearly explained, the researcher has to conduct a second interview. The purpose of having the second session was to clarify the answers which were given earlier through email and to allow the teachers to express their ideas in detail. The researcher has observed the class of the two teachers in the middle of the semester. However due to time constraint, the observation was done once which lasted for one hour only.

\subsection{Data Collection}

Data was collected through semi structured interview questions that were conducted with the two participants of the study. The interview questions were based on the teaching aspects practices of this study in order to allow teachers expressing ideas in their own ways. In order to gain additional insights into teaching practices differences, the teachers were interviewed with some questions that were related to their teaching practices as well as the challenges that they faced in class. Specifically, they were asked questions related to their lesson plans for the class; their goals of teaching; their plan to reach these goals; their students' influence on their teaching practices and on their thought on the challenges during teaching. The interview questions were adapted from Newton (2009). Although those questions were given to the student teachers (Newton, 2009) but the scope of the questions were much related to the aspect of teaching practices in this study. The teachers were also asked whether they have made reflection on what they have taught in class and how they improvise their teaching practices. They were also asked whether they have realized their mistakes during the class. The interview session lasted approximately 30 minutes for each teacher. 


\section{Results and Discussion}

Reflection provides an insight to their teaching process and role in fostering mathematical learning amongst students.

\section{Teacher 1: Miss Elizabeth}

Miss Elizabeth has 12 years of teaching experience in mathematics to the degree and diploma students in a technical institute. She has a degree in mathematics and a master in mathematics education from a local university. The researcher has observed her teaching on partial derivative.

\section{Teacher 2 Miss Yaqeen}

Miss Yaqeen has only 1 and half year of teaching experience in mathematics. She graduated in degree of mathematics from a local university and she is currently pursuing her master in philosophy of mathematics.

The justification for choosing these two distinguished teachers in terms of teaching experience is to compare their reflection on the dimension of teaching practices. Both teachers were interviewed by the researcher and their responses were summarized into a table format as shown in Table 1 below.

Based on table 1, both teachers have different interpretation on each different dimension of teaching practices. As for the preparation before the class, Miss Eliz who is more experienced than Miss Yaqeen has the idea of getting to know the students' background. She was more ready to teach compared to Miss Yaqeen who was busy practicing some questions before her new class begins. She was very confident in her teaching compared to Miss Yaqeen and her students were very focus in her class. Nonetheless, Miss Yaqeen has to do the revision on the topic that she has to teach in order to equip her with sufficient knowledge. Although her voice was very clear but she still feels nervous every time she starts her class. After a few minutes in her class, Miss Yaqeen has gained her confidence but the flow of her content delivery was not very smooth. Sometimes she has to refer to her notes while solving problems on the whiteboard. In order to be effective in mathematics teaching, teachers must understand the underlying meaning, justifications for ideas and be able to make connections among topics (Ball et al. 2005). Gradually, she is picking up the teaching skill since she used to refer to her colleagues and her diary keeps her update on how to improve her teaching day by day.

Both teachers have a different view on their teaching goals setting. The goal must be accomplished according to what has been set in the lesson plan but the less experienced teacher was more concerned about the time allocated for the class. Nevertheless, both teachers have common views on what they expect from their class which is the requirement that the students do their homework and understand the lesson. The researcher has noted that both teachers did not write their teaching goal on the whiteboard but it was mentioned verbally to the students. Some students were not aware of the goals since most of them were busy talking and making themselves comfortable in the mathematics class.

Their expectation of their classes was almost the same because both of them wanted their students to understand the lesson of the day. In addition to ensuring students are actively engaged, both teachers have assigned completing homework as compulsory. The rationale for asking them to complete their mathematics tasks was a way for them to use the drill and practice concept. Through class observation, both teachers were focused on enhancing procedural knowledge among their students. The conceptual knowledge was not fully covered since most students have problem in basic mathematics. Miss Eliz is very passionate in her teaching but she did not feel satisfied with her teaching since the students showed some interest in mathematics. She has included real life application of mathematics in her lesson in order to get them interested in her class. Making real life connections and providing support and challenges are some of the criteria mathematics teachers must have (Teaching Today, 2005).

Both of them never had a specific teaching strategy due to the different type of students. "It depends on the class that I teach. I used collaborative learning in classes consist of students who participate well in class" as what Miss Eliz stated. Due to the students' level of understanding, Miss Yaqeen used various teaching strategies in order to let the students have better understanding in her lesson. As what she has mentioned, "I used different approaches in my class just to make sure that my students understand my lesson". This is inline with the finding from Ball et al. (2005) which stated that mathematics should be taught using multiple strategies; however, the teacher is responsible for selecting the strategies appropriate for a specific concept.

As reflection is part of the teachers' learning process (Gagnon Jr. \& Collay, 2006) and it helps teachers to identify their strengths and weaknesses as a teacher. Although Miss Eliz has been teaching for more than ten years but she realized that she used to speed up her teaching. What she has said during the interview was "I seldom realize that I teach very fast until my students commented on my teaching". However, she claimed that 
she always strive to deliver the best part of her teaching to the students. The other teacher has good voice intonation when teaching but her weakness was on her English proficiency deficiency. By recognizing the strength and weakness of being Mathematics teachers, they can use these as their tool to improve the teaching skill. Selected students were called after the class and they were interviewed about what they want from their teachers. Miss Yaqeen used this method to upgrade herself especially in improving her presentation skill in her class. While Miss Eliz has taken the comment from these students to motivate her in giving the best to her students.

Apart from the dimension of the teaching practices, both teachers expressed concern that these students have caused some problems like not doing the given homework and they were passive in Miss Eliz's class. The other teacher has difficulty controlling these students and she has problem in dealing with these students' attitude. To overcome such problem, the teacher, has given these students homework on regular basis in order to help them grasp the skill in solving mathematics problem. Their students were students who are struggling in mathematics and dealing with them have made them more creative in tackling the students' problem. Miss Eliz used to call the problematic students to a different session and motivate them through personal consultation. However she is aware that her method could only be applied to limited number of students. On the other hand, Miss Yaqeen used to reward her students for good result and she gave warning to students who did not pay attention to her in the class. Since she is still young, these students sometimes ignore her warnings and make fun of it. She has problem in controlling her class. However, a senior lecturer assisted her on how to be in her class so that the students were engaged in their learning. At the end of her lesson, she would ask on the area of the improvement of her teaching and handling students. It really helps her in developing better teaching practices in the next few classes.

\subsection{Teachers' reflection on teaching practices}

In this section, the discussion focuses on the analysis of the interview and to explore the interpretation of what the data indicated about the teachers' reflection. Although this study focuses on a particular case in a specific setting but it is intended to create awareness amongst teachers that reflection is important in teaching. In addition, it could be a way of facilitating the students' learning and improving their strategy in the classroom.

Based on previous researches, it has been shown that the teachers would teach differently if they performed reflection in their teaching practices (Wood, Cobb \& Yackel, 1991). The teachers' engagement in reflection activity would benefit them as it becomes a generative growth. Indirectly, the teachers have created a community of learners through communication with others about teaching which contribute to learning and teaching aspect. Such reflection would create opportunities for changes in teachers' beliefs and their practices (Warfield, Wood \& Lehman, 2005). Based on the previous research findings, it has been yielded that there is difference in the teaching practices between experienced teachers and novice teachers (Livingston and Borko, 1990). However, integrating reflection in teaching practices may cause deficient in motivation for teachers due to lack of resources and they are overwork with additional burden. The initiative in employing reflection in teaching practices must have a constant effort in order to bring out instant rewards.

\subsection{The role of reflection in mathematics teaching practices}

In order to help students promote reflection in their teaching practices, Elias, Lope Pihie and Mahyuddin (2005) proposed some ideas that can be implemented before, during and after class. Teachers could employ ideas like making observations and comparing what they see over time; taking their attitude into consideration and exploring the conflicts that may arise as they are teaching. The suggested ideas would help the teachers to become more conscious of their decision in making the teaching strategy more effective.

The reflection process should be able to describe what happened in the teaching and learning of a Mathematics class. Teachers can ask themselves three basic questions which were suggested by Driscoll and Teh (2001) that include; what?; so what? and now what? They can write down the description of event, the analysis of event and the proposed actions following the event (Scales 2008). Gagnon Jr. and Collay (2006) stated that reflection is a productive way to manage the classroom time and keep these learners engaged until the end of the lesson. Furthermore, reflection has contributed to self improvement (Schon, 1983) which resulted in the changes of teachers' cognition and teaching practices (Cooney, Shealy \& Arnold, 1997).

\section{Conclusion}

This study does not focus on teachers' reflection solely but it focuses more on their common practices in classroom. Based on these findings, the practices of the new teacher can be distinguished from the experienced teacher. Both of them differ in terms of their preparation and the handling of students' problem. Although they are not fully aware of their reflection on their teaching practices but it leads their teaching direction to the 
common objective of the lesson. Education is unified with the idea of reflection in teaching that includes self study as the essential part of the teachers' activity (Dinkelman, 2003). The teaching process becomes a research through reflection. It involves the process of thinking and it systematizes some pedagogy aspect. Teachers should accommodate their teaching practices according to these students' ability. They have to lookout for new ways in teaching to get the students' interested in mathematics and the reflection process should be developing gradually in order to improve their teaching. The willingness to undertake the reflection process is to impart in the improvement and development of teaching practices (Scales, 2008).

For teachers who wish to promote reflection in their practices, they are recommended to use self study in their daily activities (Valli, 1989). There are various ways of reflection which will help these teachers to practice what they preach as well as improve their teaching strategy. Teachers can use journal entries or they can write a letter to themselves to impart what they have taught and what they have done in class (Gagnon, 2006). Knowledge on promoting reflection should be spread among teachers from informal discussion to more formalized interactions (Dinkelman, 2003).

Reflection process will lead to the usage of diary, logbook and journal as the evidence for these teachers' continuing development. Through reflection, the teachers will discover her passion in teaching as well as expedite their students' learning. There are many ways of promoting reflection but the main form of reflection is through teachers' journals. The journal becomes the written record of the teachers' experience and feelings about their teaching. Creative writing is one way of expressing feelings and finding the solutions for problems. When teachers write, they have to put it into habit so that they can find the specific areas for planning. Reflection should have the cycle of reflect, analyze, evaluate, learn and change (Scales, 2008). Teachers must be aware that there are different ways to learn mathematics and effective teaching practices should begin with understanding how their students think about mathematics. This is to avoid teachers from imposing their way of thinking during teaching (Allsopp et al. 2007).

\section{References}

Allsopp, D.H., Kyger, M.M., \& Lovin, A.H. (2007). Teaching Mathematics Meaningfully: Solutions for Reaching Struggling Learners. Paul H. Brooks: Baltimore.

Ball, D., Ferrini-Mundy, J., Kilpatrick, J., Milgram, J., Schmid, W. \& Scharr, R. (2005). Reaching for Common Ground in K-12 Mathematics Education. Washington, C: American Mathematical Society.

Cohen, D. K., \& Hill, H. C. (2000). Instructional policy and classroom performance: The mathematics reform of California. Teachers College Record, 102(2), 294-343.

Cooney, T. J., Shealy, B. E. and Arvold, B. (1998). Conceptualizing belief structures of preservice secondary mathematics teachers. Journal for Research in Mathematics Education, 29, 306-333.

Cross, D.I. (2009). Alignment, cohesion, and change: Examining mathematics teachers' belief structures and their influence on instructional practices. Journal Math Teacher Education, 12:325-346.

Dinkelman, T. (2003). Self study in education: A mean and ends tool for promoting reflective teaching. Journal of Teacher Education, 54, (1), Jan/February.

Doyle, W. (1990). Themes in teacher education research. In W.R. Houston, M. Haberman \& J. Sikula (Eds.), Handbook of research on teacher education (pp. 3-24). New York:Macmillan.

Driscoll, J. \& Teh, B. (2008). The potential of reflective practice to develop individual orthopaedic nurse practitioners and their practice. Journal of Orthopaedic Nursing, 5: 95-103.

Elias, H., Lope Pihie, Z.A. \& Mahyuddin, R. (2005). Competencies needed by teachers: Implications for Best Teaching Practices. Serdang: Universiti Putra Malaysia Press.

Escudero, I. \& Sanchez, V. (2007). A Mathematics Teachers' Perspective and Its Relationship to Practice. International Journal of Science and Mathematics Education, (6):87-106.

Gagnon Jr., G.W. \& Collay, M. (2006). Constructivist Learning Design. Corwin Press. Thousands Oaks, California.

Koon Shing Leung, F. (2005). Some Characteristics of East Asian Mathematics Classrooms Based on Data From The TIMSS 1999 Video Study. Educational Studies in Mathematics, 60:199-215.

Kwon, N.Y. \& Orrill C.H. (2007). Understanding a Teacher's Reflections: A Case Study of a Middle School. School Science and Mathematics, 107(6), 246-57.

Livingston, C. \& Borko, H. (1990). High school mathematics review lessons: Expert novice distinction. Journal 
for Research in Mathematics Education, 21, 372-387.

McNergney, R.F. \& McNergney, J.M. (2004). Foundations of Education, The Challenge of Professional Practice. Boston: Pearson.

National Research Council. (2001). Adding it up: Helping children learn mathematics. J.Kilpatrick, J. Swafford, and B. Findell (Eds.). Mathematics

Nelson, B.S. (1993). Implications of current research on teacher change in mathematics for the professional development of teachers. Paper presented at the Annual Meetings of the National Council of Teachers of Mathematics, 1 April, Seattle, WA, April.

Newton, K.J. (2009). Instructional practices related to prospective elementary school teachers' motivation for fractions. Journal Math Teacher Education.

Noraini Idris. (2006). Teaching and Learning of Mathematics: Making Sense and Developing Cognitive Abilities. Kuala Lumpur: Utusan Publications \& Distributors.

Scales, P. (2008). Teaching in the Lifelong Learning Sector. Berkshire: McGraw Hill Open University Press.

Schon, D. (1987). Educating The Reflective Practitioner: Toward A New Design For Teaching and Learning In The Professions. San Francisco: Jossey Bass.

Schon, D. S. (1983). The Reflective Practitioner, Temple Smith, London.Smith, M.S. 2001.Using cases to discuss changes in mathematics teaching. Mathematics Teaching in the Middle School, 7(3).

Teaching Today. (2005). Meeting Middle School Math Standards. [Online] Available: http://www.glencoe.com/sec/teachingtoday/subject/meeting-msstandards.phtml (December 31 $\left.{ }^{\text {st }}, 2005\right)$.

Valli, L. (1989). Collaboration for transfer of learning: preparing preservice teachers. Teacher Education Quarterly, 16(1), 85-95.

Warfield, J., Wood, T. \& Lehman, J.D. (2005). Autonomy, beliefs and the learning of elementary mathematics teachers. Teaching and Teacher Education, 21, 439-456.

Wood, T., Cobb, P. \& Yackel, E. (1991). Change in teaching mathematics: A case study. American Educational Research Journal, 28(3), 587-616.

Table 1. Teachers' Response based on the dimension of teaching practices.

\begin{tabular}{|c|c|c|}
\hline \multirow{2}{*}{$\begin{array}{l}\text { Dimensions of teaching } \\
\text { practices }\end{array}$} & \multicolumn{2}{|c|}{ Teachers' Response } \\
\hline & Teacher 1 (Miss Eliz) & $\begin{array}{l}\text { Teacher } 2 \\
\text { (Miss Yaqeen) }\end{array}$ \\
\hline $\begin{array}{l}\text { Preparation before the class } \\
\text { begins }\end{array}$ & Get information on students background & $\begin{array}{l}\text { Do revision like practicing some } \\
\text { related questions and prepare the } \\
\text { teaching material. }\end{array}$ \\
\hline Goal setting & $\begin{array}{l}\text { Yes, to achieve the lesson objectives and to } \\
\text { deliver the topic based on the lesson plan. }\end{array}$ & Yes, to teach within the given time. \\
\hline Expectation from class & $\begin{array}{l}\text { Student will do homework, understand most } \\
\text { of the lesson and pass the subject. }\end{array}$ & $\begin{array}{l}\text { Students are expected to } \\
\text { understand the lesson of the day. }\end{array}$ \\
\hline Teaching strategy. & $\begin{array}{l}\text { No specific method. Use collaborative } \\
\text { learning in certain classes. }\end{array}$ & $\begin{array}{l}\text { Use various teaching methods } \\
\text { which depend on students' level of } \\
\text { understanding. }\end{array}$ \\
\hline Strength of being a teacher & $\begin{array}{l}\text { Always strive hard to deliver the best to the } \\
\text { students. }\end{array}$ & $\begin{array}{l}\text { Able to give examples spontaneous } \\
\text { and have good voice intonation. }\end{array}$ \\
\hline Weakness of being a teacher. & Teach very fast. & $\begin{array}{l}\text { Not proficient teaching in English } \\
\text { and teach very fast. }\end{array}$ \\
\hline Problems in class & $\begin{array}{l}\text { Students give problems in class such as } \\
\text { being passive and they do not do their } \\
\text { homework. }\end{array}$ & $\begin{array}{l}\text { Difficult to control the students and } \\
\text { was not able to deal with students' } \\
\text { attitude. }\end{array}$ \\
\hline
\end{tabular}

